\title{
Chinese Western Cultural Relations: A Critical Analysis*
}

\author{
Muhammad Anisur Rahman Akanda \\ Shanghai University, Shanghai, China
}

\begin{abstract}
This study, within the theoretical framework of Critical Discourse Analysis, aims to explore how culture represents language, causing cultural differences between the East and the West. With a set of questions, a qualitative method is employed to collect the data in this study. By examining the 189 theoretical studies and investigating cultural and linguistic features, this study will show how culture influences culture and language, while the content analysis is completely excluded due to the limited time and space. The data will be analyzed in light of the critical discourse analysis showing how social subjects are constructed in various discourses with their personal terms. A historical change between the East and the West is the return of the ancient Silk Roads at the early 21 st century. Social changes can be seen when studying their cultural relations. Language is easily abstracted from culture. Both claim special reality of what they are. This article clearly explains how the discourse in the Chinese Western cultural relations generally reflects the social practice, the ideology, and power relations in social structures in which various discourses were published at the time of reporting. Finally, English and Chinese belong to two different language families representing linguistic differences. This makes learning English a serious challenge for Chinese native speakers.
\end{abstract}

Keywords: critical discourse analysis, Chinese Western culture, Silk Road, representation

\section{Introduction}

The critical (discourse) analysis approach applied to analyze the Chinese Western cultural relations must fit the proposed research. Frantz (2006) explained that traditional linguistic approaches have their own domains in the systems of language analysis (p. 3). The early studies focused on the systems of language analysis during the last 100 years as linguistics has become a scientific discipline, where scientific is defined as applying systemic methods of empirical and historical investigations for writing this paper. In this context, meaning is generally considered a core concept to the study of applied linguistics. Bloomfield (1933), for example, argued that meaning was so messy that it was in fact impossible to define linguistic meaning in a rigorous enough way to employ it in analyzing grammar. Chomsky $(1957 ; 1965)$ advocated that the best method of analyzing grammar was through formal learning. Both scholars believed meaning was relevant to linguistic analysis, although it could be theoretically isolated from specific instances of language use (Chomsky, 1957).

\footnotetext{
${ }^{*}$ Acknowledgements: First and foremost, I am greatly acknowledged to the School of International Exchange of the Shanghai University and the Shanghai Government Scholarship Authority for its partial financial support to undertake my PhD degree in 2015. Furthermore, I am indebted to Tang Qingye, Supervisor and Professor of discourse analysis at the School of Foreign Languages for her lectures to the graduates (November 2015-March 2016). I am also recognized to Yang Yifei, Professor of Chinese culture at the school of the International Exchange for her lectures (March 2016-May 2016). Finally, I am grateful to Professor Deng and Professor Feng for their advice on this writing. I am happy to express my gratefulness to my colleagues and friends living in China and Bangladesh for their cooperation during my stay in Shanghai.

Muhammad Anisur Rahman Akanda, Ph.D. candidate, School of Foreign Languages, Shanghai University, Shanghai, China.
} 
Researchers are trying to explore dissimilarities between two languages (Chomsky, 1965). Social scholars (Gramsci, 1971; Foucault, 1972; Habermas, 1984; Hall, 1985) have demonstrated that the social and political power may be created by, reflected in, and resisted through language use. A second generation of discourse analysis developed the main ideas of Michel Foucault, focusing on the relation between power and knowledge (Foucault, 1980). In research, the Foucault generation generated the methodological network of critical discourse analysis (CDA), most notably through the works of Fairclough (1989), Wodak (1989), and Van Dijk (1993). An examination of the roles of actors over the social practices that constitute such discourses can be an important analytical tool for CDA (Fairclough, 2003, p. 17). Discourse is responsible for the construction of our social realities, but it is neither free nor unrestricted (Foucault, 1972, p. 215). Truth represents truth and regulates discourse: One is able to distinguish between true and false statements (Foucault, 1980, p. 131). Truth endorses certain ideas while rejecting others. The ideas of some people are accepted as true, whereas those of others are rejected. This is called the critical discourse analysis to the common sense assumptions which often go unquestioned because they are believed to represent truth and reality, becoming "implicit, back grounded, taken for granted" (Fairclough, 2001, p. 77). Recently, the new dimensions have emerged from interdisciplinary connections between critical linguistics (CL) and critical discourse analysis (CDA) in the field of applied linguistics. CDA is mainly concerned with the relationship among language, ideology, and power (Fairclough, 1989; 1992; 1995a). Within the last four decades, theoretical linguistics (sociolinguistics, psycholinguistics, discourse analysis) have maintained a common connection of analyzing the language use scientifically. First, analysis must focus on meanings defined by the context of situation. Second, it requires the interpretations of situated meanings. Those who use CDA are uniquely positioned to examine how discourses are introduced, promoted, or minimized within social practices by those with more or less power (Wodak \& Meyer, 2009). With key points, a number of scholars have been contributing to the field of CDA since 1990. Fairclough (1995a) advocated that CDA is to systematically explore the opaque relationship of causality and determine between (1) discursive practices, events, and texts and (2) wider social and cultural structures, relations, and processes. In keeping in mind, I take Fairclough (1995a) and other critical discourse analysts who recognize that language use is a form of social practice (Fairclough, 1992, p. 63). CDA is a branch of discourse analysis that highlights the traces of cultural and ideological meaning. Therefore, I shall ask a few questions to explore the ideological meaning of the Chinese Western cultural relations: (1) What changes have taken place during the period of the relations between discourse change and changes in the relationship between the East and the West? (2) How is identity of the Chinese Western constructed by means of discourse through representations of subjects, actions and relations? (3) How are social subjects represented in the discourse? The question of the relationships among society, culture, and language is a highly complex question related to Williams (1981). Human subjects use texts to make sense of their world (Lucke, 1996, p. 12). Human beings are reflexive; there is always a dialectical interconnection between what they do and how they represent themselves (Fairclough, 2003, p. 18). Cultural systems help to clarify the relationship between culture and language: Cultures exist as languages. Cultures are not only discourses, but also systems and forms of consciousness (Fairclough, 2003, p. 23). CDA is especially suited to the study of media discourse, which is to uncover and examine the role of discourse in the (re)production and challenge of dominance (Van Dijk, 1993, p. 249). In a parallel study, Fairclough (1995b) advocated media language as a site of power (pp. 2-3). Media discourse is an explicit domain exposed to various ideologies which influence in life (Renugah, 2015, p. 65). For example, ZHANG (2014, p. 2273) examined the political news reports between the context of American 
and Iraq in the American Newspapers, including The NewYork Times utilizing Fairclough's framework. In line with the media discourse as a product of social practices, the Western agencies, such as Reuters, Associated Press (AP), and Agence France-Presse (AFP), dominate the national news agencies, including Xinhua and BSS (Bangladesh Sangbad Sangstha) (Hafez, 2001, p. 15; Rugh, 1979, p. 134; Bell, 1991, p. 48; Glass, 2001, p. 232). As a resource of discourse, I shall apply CDA to negotiate, challenge, and resist existing relations between China and the Western countries. This study first aims to show how language is used in various ways to express meaning. The second is that language use can change social and political issues in the Chinese Western cultural relation, which often portrays polarization. This research has been developed by the help of the second language (English) or by the use of behaviorism sciences. The findings show how the results of the research might affect theory and practice in this field. This is the background of this study, which falls into five parts. Part Two discusses literature review used in this study. Part Three examines data collection and its framework. Part Four is the central part, which focuses on the Chinese Western cultural relations. Part Five, the conclusion, summarizes the main findings, including implications, limitations, and suggestions for further research.

\section{Literature Review}

This part aims to explore the early historical and empirical reviews of the Chinese Western cultural relations because of many reasons. China rises dramatically in modern world, which will become tomorrow's biggest power that influences the Western countries. The rise of China has become a great factor into the broader regional discourse (Chandra, 2015, p. 220). China's rise needs to be studied by all countries for two reasons: One is led by China and the other by almost all Asian and Western countries (Africa, America, \& Europe). It was during the 1970 s that early projects were taken to explore the possibility of regional cooperation in South Asia by the European funding agencies (United Nations Development Programme, Asian Development Bank) for undertaking research (Chandra, 2015, p. 182). As an old Chinese saying goes, we can always get a better understanding of the present by reviewing the past (BD-China Embassy, 2017). With this aim, I have to write this part to explore the early cultural relations between the East and the West. Confucius and Socrates are the two great thinkers from China in the Orient and from Greece in the West during the 6th and 5th centuries BC (Robertson, 1943, p. 231). They have widely influenced over the ancient civilizations of the Chinese and the Greek in their own historical periods. Socrates (born in 470 BC) lived when the slave-owning democracy was the golden age of the ancient Athens. Confucius (born in 551 BC) lived in the state of Lu during the Chun Chiu Period (722-481 BC) when the ancient slave system was at the point of collapse in China. When ancient China entered its slavery period (ca. 2500 BC), the clan system had not been thoroughly abolished from earth. China's first dynasty (Xia) marked a change from a primitive society to a slave society. Three dynasties (Xia, Shang, and Zhou) were the historical representations of their social subjects. Socrates and Confucius maintained their own ethics in society. Confucius said "Goodness is more to the people than water and fire" (Analects $X V$, p. 334). "Virtue is knowledge" is the famous discourse of Socrates. Confucianism is reminiscent of Socrates's ideas and wisdom. Without wisdom, it was impossible to realize virtue. Within different cultural backgrounds, the social systems of Confucius and Socrates had their own ideas with treasures of world culture. Socrates had influence on the Western philosophy of language and culture, while Confucianism influenced Chinese society, politics, culture, and psychology during the last 2400 years. The Roman Empire and the Han Dynasty were two powerful influential forces in their heyday (Robertson, 
1943, p. 231). The Han Dynasty emerged as a principal power in East Asia in 221 BC when the Silk Roads started from Xian to Mediterranean Sea. Their influence was so profound that the Han Dynasty was termed as a golden age because their goods were in high demand in Roman cities (Wagner, 2001, p. 73; Li Bo, 2001, p. 229). In ancient times, the Silk Roads were a meeting place of world cultures and religions, first for Buddhism and later for Islam and Christianity (Washington, 1988; ZHANG, 2010, p. IV; The Independent, 1 September 2016, p. 11). The Silk Road was originated from the silk produced by silk-worms, which was the symbol of the Asian civilization. Roman was mad about the silk because silk was a luxurious goods and diplomatic gifts. At that time, the silk trading was famous with three roads: (1) Northern Silk Road; (2) Maritime Silk Road; and (3) Southern Silk Road. Chinese scholars believe that Southern Silk Road was the earliest link between China and Western countries (ZHANG, 2010, p. II; Ahmed, 2013, p. 283). It was a big bridge for cultural, scientific, and business exchanges between the East and the West (ZHANG, 2010, p. III; Keay, 2011, p. 220; Allan, 2013, p. 145 ). Four great inventions (papermaking, printing, compass, and gunpowder) were introduced to the West while knowledge of astronomy, calendar, mathematics, architecture, sculpture, and geography were introduced with Buddhism from India to China in the year 2BC. The Silk Road was an original passage through which, some of the ancestors in the West came from Sichuan, Yunnan, Tibet, and Mongolia (ZHANG, 2010, p. V; Uddin, 2013, p. 230; Sarker, 2014, p. 74). Chinese monks (Yijing, Xuanzang) traveled to the Buddhist monasteries between 5 th and 7th centuries to acquire knowledge in the West. The Maritime Silk Road opened for the geographical features during Tang and Song Dynasties. ZHENG He (1405-1433) was the commander of the treasure voyages to the costal territories and Islands around the South China Sea and the Indian Ocean. The works of social scholars (Ma Huan, Fei Xin, \& Gong Zhen) unfold before us a picture of the Chinese Western cultural relations for over two thousand years. In the early 21 st century, at the age of 63 years old, XI Jin-ping, the President of China and General Secretary of the Communist Party, wants to revive the ancient Silk Road across the old trade route (Xinhua \& BSS, 14 October 2016). It marks the return of a legend, having historical and linguistic references to "yi dai yi lu" (a belt, a road). It is a gigantic project covering about 60 countries and half of population in the world. That is why China wants to expand trade route and develop infrastructures globally. President XI declared the new concept in Kazakhstan in the September 2013. In order to finance the project, China has already established the Asian Infrastructure Investment Bank (AIIB) avoiding the wills of Washington, World Bank (WB) and International Monetary Fund (IMF). In June 2015, the 57 countries, including France, Great Britain, and Germany, signed the charter of the AIIB. The Western media (AFP, 15 May 2017) reported that China hosts its Silk Road with the North Korean missile in 2017, asking the question: What is Beijing trying to achieve with its Silk Road plan? With a reply, the 21st Century Maritime Silk Road will connect China with Southeast Asian countries, Africa, and Europe (Islam \& Askari, 2015, p. 18). The project will show a strategic Chinese presence in the Indian Ocean and the Asian region for other countries. In a geographical location, the Belt is an overland network bringing together China, Central Asia, Russia, and Europe, linking China with the Persian Gulf and the Mediterranean Sea and also connecting China with South Asia and Indian Ocean (Islam \& Askari, 2015, p. 23). The Road means a maritime network linking China's coast to Europe through the South China Sea and the Indian Ocean in one route and China's coast to the South Pacific through the South China Sea in another. In an ideal scenario, the new Silk Road can become the biggest economic trade route since the Marshall Plan, with which the United States helped Germany get back on its feet after World War II (The Independent, 12 June 2015). Russian President Vladimir Putin believes Beijing aims to solidify its dominant political position with the Silk Road plan that Iran and Turkey strongly support. The first 
direct train from China arrived in Tehran in the February 2016. Bangladesh and China have the prospect to build the $900 \mathrm{~km}$ Kunming Highway linking Chittagong with Kunming through Myanmar to facilitate cultural relations (Ahmed, 2013, p. 279). The most advanced southern countries (China, India, Brazil, Russia, and South Africa) are advocating for south to south cooperation with their foreign aids (Islam \& LI, 2014, pp. 10-12). The cooperation is termed as the rise of China and India as a southern economic power in less than 20 years as fast as that during the Industrial Revolution in Europe and North America (Roca, 2013, p. 164). This study considers only the Chinese Western cultural relations having many years and centuries; many problems both have facing in the 21st century (Ahmed, 2013, p. 286; Sarker, 2014, p. 83). Confucius's main goal is to achieve a world of peace and harmony (Hsu, 1991; CHEN \& Lee, 2008). China develops this relationship with its recipient country in a friend to friend manner (Lengauer, 2011, p. 35). The most important problem is the language barriers of causing difficulties to transfer knowledge and technology from China to the West. The last four decades was a critical period for China at various levels, with whom, the Western countries are going ahead with the spirit of the ancient Silk Roads. Climate change is one of the biggest threats to all the countries; therefore, all need to share their adaptation lessons and experiences. The relations between China and the Western countries must develop even more if the Western media reflects the audiences with their special articles. In the past, Reuter Telegram Company (founded in 1851) was one of the oldest news agencies in the world and had its branches in different parts of British India and China (UNESCO, 1953, p. 11). Reuters is originally connected with the World agencies (AP, AFP, \& UPI-United Press International) and the 180 national news agencies, which have representations in the shape of stringers (Ministry of Information, 2008, pp. 472-473). It gets foreign news through satellite from the World and news agencies. The Western media have always tried to distinguish between culture and language. Chinese culture is guided by the instructions of Buddhism while the Western culture is spirited by Christianity. Both vary in their languages, which are highly considered to be territorial as they dominate the communication system of their respective locations. Chinese is the ruling language of the East originating from the Huns; English reigns as the language of the West as it becomes the language of the world by default. This study represents a social picture of the 189 discourses, a social change towards the peoples, who are the audiences for the topic "Chinese Western cultural relations" though it is a field of political science and global studies. A few scholarly books have been written by the Chinese and Western scholars in English, who have adopted the realist approach to study the diplomatic and economic relations. Application of critical discourse analysis (CDA) on the Chinese Western cultural relations has been neglected in the country for a long time. Basically, it is politically related with the term, International Relations (IR) from the time of the Greek historian, Thucydides, who is considered to be the founding father of the realist school of political philosophy (Cochrane, 1929, p. 179). Bangladeshi scholars (Haider, 2006; Rashid, 2010; Pandey, 2013; Uddin, 2013; Parlene, 2013) discussed about South Asian countries' economic relations with China while Bangladesh relations were discussed with India, Pakistan, US (United States), USSR (Union of Soviet Socialist Republics), China, and the Muslim World at the dawn of the 21st century. Further research is urgently needed for the content analysis of the media discourse of the Chinese Western cultural relations in light of the critical discourse analysis.

\section{Data Collection and Theoretical Framework}

Social scholars distinguish between data collection and data analysis. According to Grounded theory (Glaser \& Strauss, 1967), data collection is not a phase that must be finished before analysis starts but it might 
be a continuous procedure. In this mode, data collection is never completely excluded if new data are collected or earlier data are re-examined (Strauss, 1987, p. 56). This connection between theory and discourse can be described in terms of critical discourse analysis as there is no traditional way of collecting data. Some scholars do not even mention the method of data collection and the others depend strongly on the traditional sociolinguistic field. In a practical sense, complete discourse analysis of a text or talk is therefore totally out of the question. However, my research methodology consists of course work, field work, and data analysis, specialized in the major of language, culture, and world civilization at Shanghai University in 2015. As it is an empirical research, I take qualitative method and I collect the selected data on the Chinese Western cultural relations from representative books, journals, articles, and web links listed at the end as reference. The data for this study include the 329 studies: 189 theoretical and 140 news reports. Since data collection is a continuous process, data analysis will aim to answer the research questions. The 140 news reports focusing on the Sino-Bangladesh relations were completely excluded from this analysis. Online searches were driven in June, July, September, and October 2016. In conducting the theoretical framework, the search was first executed in the ProQuest Scholarly Journal database and Google Scholar. Initially, 189 related studies were downloaded from the ProQuest database and Google Scholar. Of them, 53 studies were eliminated due to the absence of the theoretical framework. Only 79 studies applying CDA approaches were included and reviewed. Of the 57 studies, the content was analyzed according to the major theoretical framework. I essentially use the official websites of the Ministry of Information, the Ministry of Foreign Affairs, BD-China Embassy, many other journals, and dissertations as secondary data sources to prepare this article. After analyzing the content, the selected studies were organized under two major themes. The first theme is concerned with the critical discourse analysis (CDA), the second with the Chinese Western cultural relations. The reference shows a summary of the theoretical studies according to authors, year of publication, sources of data, and findings. This study adopts Norman Fairclough's (1995a) theoretical framework to capture the complex relationships between the Chinese Western context and the social structures.

\section{Chinese Western Cultural Relations}

This study aims to explore the early cultural and linguistic representations of the Chinese Western cultural relations. What is the culture that is different from other countries? A society's culture is made up of all its ideas and ways of behaving. Among the definitions, Sir Edward Burnett Tylor (1871) proposed three stages of culture: (1) savagery, (2) barbarism, and (3) civilization. Morgan (1877, p. 12) showed the cultural development of ancient society. Murdock's (1949) social structure was famous for studying the 700 cultural headings from ethnographies by Boas and Malinowski into the cross cultural survey, the Human Relations Area Files (HRAF) from the Science of Man in the World Crisis (Murdock, 1949, p. 123). Theorists believe that people engage in the social events primarily in order to predict similar events in the future (Heider, 1958; Jones, 1979). Eggan (1961, pp. 125-127) suggested the anthropological concept to test hypotheses about the nature of society's culture (Naroll, 1961, p. 221; Levinson, 1979). Gramsci (1988) followed the cultural hegemony of Forgacs (1988, p. 234). Psychologists have observed the Western cultures in East Asia with Chinese, Indians, Koreans, and Japanese (Ross \& Nisbett, 1991; Choi \& Nisbett, 1998, p. 949). Regional comparison is the key to define classifications of cultures and make inferences about processes of diffusion within a cultural region (Levinson \& Melvin, 1996, p. 263). Culture produces language, which is not a process of habit formation but a process of rule formation according to Noam Chomsky $(1965 ; 1983)$ who seeks to discover the highly abstract 
principles of language. Chomsky (1965) shows some principles as "negative evidence", which is the essence of all human languages because of human nature. Chomsky (1983) has developed the contrastive analysis (Ellis, 1985, p. 191). First, all human languages follow the similarity in two structures: (1) SVO languages (subject + verb + object) in English and (2) SOV languages (subject + object + verb) in Chinese. In both structures, there is no "wild grammar". Second, difference can be seen by the analysis that mistakes occur when learners fail to perform their competence (Corder, 1967; Ellis, 1994). Social scholars (Cook, 1985; White, 1989) mentioned three differences in language: (1) internal complex principles, (2) ungrammatical sentences, and (3) grammar learning. With those differences, Chinese classical painting often aims to reflect the harmony of painter's spirit with the painting's meaning while Western classical painting contains reasonable logic, reflected in English syntactic constructions (ZHENG, 1992, p. 227). Chinese aesthetics is deeply influenced by Confucianism and Taoism, reflected in Chinese classical paintings and Chinese language (ZHU, 2015). Both painting and language are inherently interlinked with culture, history, and national ideologies (DONG \& MA, 2017, p. 82). Within linguistic differences, parataxis is the main grammatical feature of Chinese sentences while hypotaxis is the main grammatical feature of English (DONG \& MA, 2017, p. 80). The concepts of parataxis and hypotaxis for sentence constituents were mentioned by Halliday (1994, p. 218), Nida and Taber (1969, p. 168), and WANG (2007, p. 409). The Chinese subject-predicate structure is flexible and the sentence pattern is diffusive, with the clauses connected by parataxis (LIAN, 1993). Chinese has no alphabet and articles but uses a logographic system, where the subject and verb are not inverted as in English. Chinese sentence structure is so flexible that a subject is not essential in a sentence, which is different from English (LIAN, 1993). Because of this difference, Chinese learners may fail to use English modals sufficiently. Since the lexical feature does not exist in Chinese, Halliday (1994; 2009) worked to explore the linguistic differences between English and Chinese, two big languages together with Spanish, the big three of the world in the field of institutional linguistics. According to Fairclough (1992, p. 144), the systemic inability to interpret meanings within situations is a clear reflection of sociolinguistics in which language functions as a social system, which removes the social imbalances between languages and cultural changes. In those days, most of the scholars were increasingly becoming hesitant to use their basic theoretical concepts, such as power, ideology, class, and truth (Fairclough, 1995a, p. 15). Discourse is use of language seen as a form of social practice and discourse analysis is analysis of how texts work within socio-cultural practice (Fairclough, 1995a, p. 7). At three levels, social institutions are determined by the social formation, while social action is determined by social institution (Fairclough, 1995a, p. 37). A language is a network of systems for making meanings (Halliday, 1994, p. 15). A critical awareness of language overcomes social problems (Fairclough, 1995a, p. 223). In this study, I have chosen two approaches of critical discourse analysis to explore the social subjects of the Chinese Western cultural relations. My first approach is Halliday's (1994) systemic functional analysis to answer the first research question: Who are the social subjects and what are the social actions? The Subject is one of the major concepts in the Western linguistics. In ancient Greece, each clause contains one element which can be identified as its Subject, the doer of the action. There are three definitions, which are not synonymous, but different in meaning. The social subjects are clearly interpreted by Halliday (1994, p. 30) as psychological Subject (Theme), grammatical Subject (Subject), and logical Subject (Actor). What is the significant of being three distinct functions in the clause, Subject, Actor, and Theme? This is believed that Subject, Actor, and Theme are three functions located at three clauses: (1) The "Theme" functions in the structure of the clause as a message; (2) the "Subject" functions in the structure of the clause as an exchange; and (3) the "Actor" functions 
in the structure of the clause as a representation. Three headings (ideational, interpersonal, textual meanings) refer to the transitivity system depending on their configurations and technical names. Language enables human beings to build a mental picture of their reality, although there is no priority of one kind of process over another, but they form a circle and not a line (Halliday, 1994, p. 108). What is the status of a process in the grammar of the clause? Its framework consists of three parts: (1) process itself, (2) participant in the process, and (3) circumstance with the process. These three components are typically realized in three ways. Participant is the social subject; process is the social action and circumstance is the social relation. My second approach is Fairclough (1995a) who proposed a critical discourse analysis to analyze situated meanings in the context of social change (p. 15). Who are the social subjects and what are the social actions? The answer is that Institutional subjects are called social subjects, which occupy subject positions in a variety of institutions (Fairclough, 1995a, p. 39). In preferring subjects, he emphasizes that discourse makes people and people make discourse ideologically. According to Coward and Ellish (1977, p. 77), ideology produces subjects, which are freed, homogeneous, and responsible for their actions. Ideologies reside in texts and language is a material form of that ideology (Fairclough, 1995a, p. 73). It is the hegemonic control of the dominant class over the institutions of civil society (Fairclough, 1995a, p. 91). As social practice, the analysis of the discursive event may refer to different levels of social organization, such as context of situation, institutional context, and context of culture (Malinowski, 1923; Halliday \& Hasan, 1985). Three dimensional models (text, discourse practice, social practice) can contribute to the representations of the social subjects, social actions, and relations (Fairclough, 1995a, p. 98). This study needs to answer the second research question: How are the social subjects represented? The social subjects, social actions, and relations are represented with grammatical features (Frantz, 2006, p. 351). The way in which subjects are identified, named with the use of nominal groups. Identifying subjects with nouns makes everyone to whom it is applied a political subject. The actions of social subjects can be represented linguistically with verbs or verb phrases, tense, modality, and voice. The relations of social subjects are represented with the use of circumstances, including adverbial clause and prepositional phrase. The third research question: How is identity of the Chinese Western constructed in this paper? The answer is like that a message consists of a Theme combined with a Rhyme at the clause as a message (Halliday, 1994, p. 38). The Theme must come first and then the Rhyme at the clause. Bell and Garrett $(1998$, p. 18) recommended Fowler (1994, pp. 39-42) who considered Halliday's framework the best tool for examining the connections between linguistics and ideology. Therefore, this study advocates Fairclough's (1995b) media discourse as a site of power, which can influence knowledge, social relation, social subjects, and identities (p. 2). This study has also investigated into the social meanings of the Chinese Western cultural relations to the linkage connection among discourse, ideology, and power to those involved in social practice (Fairclough, 1993, p. 134). To understand the impact of the media discourse, CDA offers a very promising tool for the complex relationships between the Chinese Western context and the social structures. More research on the Media discourse will be included in future if the Chinese Western cultural relations increase to a great extent.

\section{Conclusion}

The findings show how the social subjects are constructed through the discourse of the Chinese Western cultural relations. Part Two and Part Four detailed the cultural and linguistic representations of the social subjects and their actions. What changes have taken place during the period of the relations between discourse change and changes in the relationship between China and the Western countries? This study must try to reflect 
the mind of the majority population towards the Chinese Western cultural relations and social structures. The findings show how the English clause is combined with three functional structures: (1) Transitivity, (2) Mood, and (3) Theme. The social subjects are typically realized by the grammar of the Chinese Western cultural relations, which are the two dominant Themes of their thoughts and actions. The ideational theme is the representation of the Actor, while the interpersonal theme is the exchange of the Subject and the textual theme is the message of the Adjunct. The "Chinese Western" is realized with the concept of the "Theme + Rhyme" structure (Halliday, 1994). Chinese is the Theme while Western is the Rhyme. Both are the social subjects represented with the use of personal terms, which is a key device in understanding them. Confucius and Socrates are two social subjects with whom the power is associated as this encounter usually takes place between the power holder and the powerless (Renugah, 2015, p. 63). Therefore, CDA can make a big bridge between cultural changes with the careful examination of the discourse practices (Van Dijk, 2005, p. 66; Billig, 2003 , p. 228). Chinese culture is one of the world's oldest cultures consisting of three sovereigns and five emperor periods with the geographical territories of the 56 ethnic groups. After the 2000 years dynastic rule, modern China was constituted with the power of the Congress in 1978. With the Rise of European power, Sino-American, Sino-Japanese, and Sino-British relations were improved significantly at the end of the 20th century. During the 1911 Revolution, Zhong-Shan style clothes represented the Western clothes for the Chinese. There are always five buttons and four pockets on the garment. The five buttons represent five principles (legislation, supervision, examination, administration, and jurisdiction) and four pockets represent four virtues (propriety, justice, honesty, and shame), and three cuff-buttons represent three principles (nationalism, democracy, and livelihood). In the early 21st century, the return of the ancient Silk Road (one belt one road) is also the social subject for the economic development primarily in Eurasia. The Chinese face with visa restrictions and language barriers; they have no enough cash to visit Sydney, Paris, or New York. Most of the foreigners in China are the mix of Europeans, Australians, and North Americans. Differences can be seen when studying their culture and language. English and Chinese, two different language families represent linguistic differences (Robert, 1987, p. 11). This makes learning English a serious challenge for Chinese native speakers. As I have to build a hypothesis for this study, my hypothesis is the Chinese Western cultural relations. China and the Western countries will be benefited in their relations and it brings a bright future for them. This study was limited to the critical discourse analysis of the Chinese Western cultural relations. Another limitation was the lack of the content analysis of media discourse, which will be discussed in my $\mathrm{PhD}$ dissertation in terms of "Critical discourse analysis of the Media representations of Sino-Bangladesh relations (1975-2015): A case study on the BSS". If this relation will develop more, many issues will be included with those relations in future.

\section{References}

Ahmed, SM S. (Ed.). (2013). Bangladesh-China relations: Scopes for attaining new heights. BIISS Journal, 34(4), $273-292$.

Allan, J. A. (2013). The Cambridge shorter history of India (p. 145). United States: Literary Licensing.

BD-China Embassy. (2017). Retrieved from http://bd.china-embassy

Bell, A., \& Garrett, P. (1998). Approaches to media discourse. Wiley-Blackwell (March 6, 1998). ISBN-10: 0631198881.

Bell, A. (1991). The language of news media. Oxford: Blackwell.

Billig, M. (2003). Political communication. In D. O. Sears, L. Huddy, and R. Jervis (Eds.), Oxford handbook of political psychology (pp. 222-250). New York: Oxford University Press.

Bloomfield, L. (1933). Language. New York: Holt.

Chandra, V. (2015). India and South Asia: Exploring regional perceptions, institute for defense studies and analyses. New Delhi: 
Indian Foreign Affairs Journal.

CHEN, C., \& Lee, Y. (2008). Leadership and management in China: Philosophies, theories, and practices, centre for digital philosophy (p. 7). Cambridge: Cambridge University Press.

Choi, I., \& Nisbett, R. E. (1998). Situational salience and cultural differences in the correspondence bias and the actor-observer bias. Personality and Social Psychology Bulletin, 24, 949-960.

Chomsky, N. (1957). Syntactic structure. The Hague: Mounton.

Chomsky, N. (1965). Aspects of the theory of gramma. Cambridge: MIT Press.

Chomsky, N. (1983). Mental representations. Syracuse Scholar (1979-1991), 4(2). Retrieved from https://surface.syr.edu/suscholar/vol4/iss $2 / 2$

Cochrane, N. C. (1929). Thucydides and the science of history (p. 179). Oxford: Oxford University Press.

Cook, V. J. (1985). Chomsky's universal grammar and second language learn. Applied Linguistics, 6, 2-18.

Corder, S. P. (1967). Significance of learners' errors. International Review of Applied linguistics, 5, 161-169.

Coward, R., \& Ellis, J. (1977). Language and materialism: Developments in semiology and theory of the subject. London: Routledge and Kegan Paul.

DONG, M., \& MA, Q. (2017). A comparative study of syntactic hypotaxis and parataxis in English and Chinese from the aesthetic perspective of classical painting. Canadian Social Science, 13(4), 80-83. doi: 10.3968/9549. Retrieved from www.cscanada.net

Eggan, F. (1961). Ethnographic data in social anthropology in the United States. The Sociological Review, 9(1), 19-26. Retrieved from http://onlinelibrary.wiley.com/doi/10.1111/j.1467-954X.1961.tb01083.x/abstract

Eggins, S., \& Slade, D. (1997). Analyzing casual conversation. London: Cassel.

Ellis, R. (1985). Understanding second language acquisition. Oxford: Oxford University Press.

Ellis, R. (1994). Factors in the incidental acquisition of second language vocabulary from oral input: A review essay. Applied Language Learning, 5, 1-32.

Fairclough, N (1989). Language and power. London: Longman.

Fairclough, N (1992). Discourse and social change. Cambridge: Polity Press.

Fairclough, N. (1993). Critical discourse analysis and the marketization of public discourse. Discourse \& Society, 4, 133-168.

Fairclough, N. (1995a). Critical discourse analysis: The critical study of language. London: Longman.

Fairclough, N. (1995b). Media discourse. London: Edward Arnold.

Fairclough, N. (2001). Language and power. London: Longman.

Fairclough, N. (2003). Political correctness: The politics of culture and language. Discourse \& Society, 14(1), 17-28.

Forgacs, D. (1988). Gramsci reader. London: Lawrence and Wishart.

Foucault, M. (1972). The archaeology of knowledge (translation by A. M. Sheridan Smith). London: Tavistock.

Foucault, M. (1980). Power-knowledge: Selected interviews and other writings (1972-1977). C. Gordon (Ed.). New York: Pantheon Books.

Fowler, R. (1994). Language in the news. London: Routledge.

Frantz, R. S. (2006). The linguistic constructions of agency and identity in gay VS mainstream media coverage of same sex marriage: A critical discourse approach. Retrieved from ProQuest LLC 2007 (Publication No. UMI 3237083).

Glaser, B., \& Strauss, A. (1967). The discovery of grounded theory. Chicago: Aldine.

Glass, D. (2001). The global flow of information: A critical appraisal from the perspective of Arab-Islamic information sciences, mass media, politics and societyin the Middle East (pp. 217-240). Cresskill, NJ: Hampton Press, Inc.

Gramsci, A. (1971). Selections from the prison notebooks. Q. Hoare and G. Nowell Smith (Eds.). New York: International Publishers.

Gramsci, A. (1988). An Antonio Gramsci reader: Selected writings. D. Forgacs (Ed.). New York, NY: Schocken.

Habermas, J. (1984). The theory of communication action (Vol. 1). London: Heinemann.

Hafez, K. (2001). Mass media in the Middle East: Patterns of political and societal change. In K. Hafez (Ed.), Mass media, politics and society in the Middle East (pp. 1-20). Cresskill, NJ: Hampton Press, Inc.

Haider, Z. (2006). The changing pattern Bangladesh foreign policy: A comparative study of the Mujib and Zia Regime. Dhaka: The University Press Ltd.

Hall, S. (1985). Signification, representation, ideology: Althusser and the post structural debates. Critical Studies in Mass Communication, 2, 91-114.

Halliday, M. A. K. (2009). Language and society. In J. W. Jonathan (Ed.), Collected works of M. A. K. Halliday (Vol. 10). 
London: Continuum.

Halliday, M. A. K., \& Hasan, R. (1985). Language, context and text. Geelong, Victoria: Deakin University Press.

Halliday, M. A. R. (1994). An introduction to functional grammar (2nd ed.). London: Edward Arnold.

Heider, F. (1958). The psychology of interpersonal relations. New York: Wiley.

Hsu, C. (1991). Applying Confucius ethics to international relations. Journal of Ethics and International Affairs, 5(March/April). Islam, A. T. M., \& LI, X. Y. (2014). South-south cooperation-policy and practice by the export import bank of China. Journal of Economics and Finance (IOSR-JEF), 3(1), 9-19. Retrieved from www.iosrjournals.org

Islam, N. I., \& Askari, M. M. R. (2015). Belt and road initiative of China: A new hope in the region. Bangladesh Journal of Tariff and Trade, 4.

Jones, E. E. (1979). The rocky road from acts to dispositions. American Psychologist, 3, 107-117.

Keay, J. (2011). India: A history. New York, NY: Grove Press.

Lengauer, B. S. (2011). China's foreign aid policy: Motive and method. The Bulletin of the Centre for East-West Cultural and Economic Studies, 2, 35-81.

Levinson, D., \& Melvin, E. (1996). Comparative method. New York: Encyclopedia of Cultural Anthropology.

Levinson, S. (1979). Activity types and language. Linguistics, 17, 365-399.

Li Bo, Z. (2001). 5000 years of Chinese history. China: Inner Mongolian Publication.

LIAN, S. E. (1993). Contrastive studies of English and Chinese. Beijing: Higher Education Press.

Lucke, A. (1996). Text and discourse analysis. New York: American Educational Research Association.

Malinowski, B. (1923). The problem of meaning in primitive languages (Supplement 1). In C. Ogden and I. A. Richards, The meaning of meaning. New York: Harcourt Brace.

Ministry of Information. (2008). Law \& regulation publication: Bangladesh Sangbad Sangstha (BSS). Dhaka: Ministry of Information.

Morgan, L. H. (1877). Ancient society (Chapter 1-2). Retrieved from https://en.wikipedia.org/wiki/Ancient_Society

Murdock, G. P. (1949). Social structure. New York: The MacMillan Company. ISBN: 0-02-922290-7. Retrieved from https://en.wikipedia.org/wiki/George_Murdock

Naroll, R. (1961). Two solutions to Galton's problem. In F. Moore (Ed.), Readings in cross-cultural methodology (pp. 221-245). New Haven: HRAF Press.

Nida, E. A., \& Taber, C. (1969). The theory and practice of translation. Netherlands: E. J. Brill.

Pandey, N. (2013). China in South Asia: Future possibilities. In B. M. Kabir (Ed.), Sino-South Asian relations (pp. 57-68). Chittagong: University of Chittagong.

Parlene, A. (2013). Importance of the free trade agreement between Bangladesh and China. In B. M. Kabir (Ed.), Sino-South Asian relations (pp. 280-314). Chittagong: University of Chittagong.

Rashid, H. ur. (2010). Bangladesh foreign policy: Realities, priorities and challenges. Dhaka: Academic Press and Publishers Library (APPL).

Renugah, R. B. H. T. (2015). Application of critical discourse analysis in media discourse studies. The Southeast Asian Journal of English Language Studies, 21(2), 57-68. Retrieved from https://www.researchgate.net/

Robert, R. (1987). The languages of China. Princeton: Princeton University Press.

Robertson, D. S. (1943). Greek and Roman architecture (2nd ed., p. 231). Cambridge: Cambridge University Press.

Roca, T. (2013). Human development report: The rise of the south, human progress in a diverse world. Afrique Contemporaine, 246(2), 164. Retrieved from //www.cairn.info/revue

Ross, L., \& Nisbett, R. E. (1991). The person and the situation: Perspectives of social psychology. New York: McGraw-Hill.

Rugh, W. (1979). The Arab Press: News media and political process in the Arab world. London: Syracuse University Press.

Sarker, N. M. (2014). Bangladesh-China relationship at the dawn of the twenty first century. Peace and Security Review, 6(11), 72-96.

Sir Edward Burnett Tylor. (1871). Primitive culture (Vols. 1-2). London: John Murry. Retrieved from https://en.wikipedia.org/wiki/Edward_Burnett_Tylor

Strauss, A. L. (1987). Qualitative analysis for social scientists. Cambridge: Cambridge University Press.

Uddin, A. G. M., Niaz. (2013). Political dimensions of Sino-Bangladesh relations: Recent trends. In B. M. Kabir (Ed.), Sino-South Asian relations (pp. 230-241). Chittagong: University of Chittagong.

UNESCO. (1953). News agencies, structure and operation. The United Nations Educational Scientific and Cultural Organization, Gorges Lang, Paris, France YC.52.D.1t1A. 
Van Dijk, T. (1993). Principles of critical discourse analysis. Discourse Society, 4(2), 249-283. Retrieved from http://das.sagepub.com/content/4/2/249

Wagner, D. B. (2001). The state and iron industry in Han China. Copenhagen: NIAS Publishing.

WANG, J. Q. (2007). Thoughts on hypotaxis and parataxis. Foreign Language Teaching and Research, 39(6), 409-416.

White, L. (1989). Universal grammar and second language acquisition. Amsterdam: John Benjamins.

Williams, R. (1981). Culture. London: Fontana.

Wodak, R. (1989). Language, power and ideology: Studies in political discourse. Amsterdam: Benjamins.

Wodak, R., \& Meyer, M. (2009). Methods of critical discourse analysis. London \& New York: Longman.

ZHANG, M. (2014). A critical discourse analysis of political news reports. Theory and Practice in Language Studies, 4(11), 2273-2277. Retrieved from http://www.ojs.academypublisher.com/index

ZHANG, X. Y. (2010). History and legend of Sino-Bangla contacts. Dhaka: Embassy of China to Bangladesh.

ZHENG, C. M. (1992). Comparison between Chinese culture and western culture (pp. 225-240). Beijing: Beijing Language College Press.

ZHU, L. Y. (2015). History of western aesthetics. China: Higher Education Press. 